\title{
Space-time variation of the relative abundance of Limnoperna fortunei in deep zones of São Gonçalo Channel, Rio Grande do Sul, Brazil
}

\author{
Michelle Lopes $^{1} \&$ João Vieira ${ }^{2}$ \\ 1. Universidade Federal do Rio Grande (FURG), Programa de Pós-Graduação de Biologia de Ambientes Aquáticos Continentais. Av. Itália, Km 08, Caixa Postal 474, 96201-900, Rio Grande, \\ RS, Brasil. (michellenlopes@gmail.com) \\ 2. Universidade Federal do Rio Grande (FURG), Instituto de Oceanografia, Laboratório de Ictiologia. (vieira@mikrus.com.br)
}

\begin{abstract}
This work describes the spatial-temporal variation of the relative abundance and size of Limnoperna fortunei (Dunker, 1857) collected in São Gonçalo Channel through bottom trawl with a $0.5 \mathrm{~cm}$ mesh, at depths between 3 and $6 \mathrm{~m}$. The estimative of mean relative abundance (CPUE) ranged from 2,425.3 individuals per drag (ind./drag) in the spring to 21,715.0 ind./drag in the fall, with an average of 9,515.3 ind./drag throughout the year. The estimated mean density of $L$. fortunei for the deep region of São Gonçalo Channel ranged from 1.2 to 10.3 ind./ $\mathrm{m}^{2}$, and it was recorded a maximum density of $84.9 \mathrm{ind} . / \mathrm{m}^{2}$ in the fall of 2008 . The method of sampling using bottom trawl enabled the capture of $L$. fortunei under the soft muddy bottom of the channel, in different sizes ranging from 0.4 to $3.2 \mathrm{~cm}$. This shows that the structure of the $L$. fortunei adult population under the bottom of the São Gonçalo Channel is composed mostly of small individuals $(<1.4 \mathrm{~cm})$, which represent up to $74 \%$ of the population collected.
\end{abstract}

KEYWORDS. Freshwater invasion, frequency of sizes, golden mussel, bivalve.

RESUMO. Variação espaço-temporal da abundância relativa de Limnoperna fortunei em zonas profundas do canal São Gonçalo, Rio Grande do Sul, Brasil. Este trabalho descreve a variação espaço-temporal da abundância relativa e tamanho de Limnoperna fortunei (Dunker, 1857) coletados no Canal São Gonçalo através de rede de arrasto de fundo com malha $0,5 \mathrm{~cm}$, em profundidades entre 3 e $6 \mathrm{~m}$. As estimativas de abundância relativa média (CPUE) variaram de 2.425,3 ind./arrasto, na primavera a 21.715,0 ind./arrasto no outono, com média de 9.515,3 ind./ arrasto ao longo do ano. A densidade média estimada para L. fortunei para a região profunda do Canal São Gonçalo variou de $1,2 \mathrm{a} 10,3$ ind./ $/ \mathrm{m}^{2}$, sendo registrada uma densidade máxima de 84,9 ind. $/ \mathrm{m}^{2}$ no outono de 2008 . O método de coleta com arrasto de fundo possibilitou a captura de $L$. fortunei sob o fundo mole lodoso do canal, em tamanhos variando de 0,4 a $3,2 \mathrm{~cm}$, revelando que a estrutura da população adulta de $L$. fortunei sob fundo do Canal São Gonçalo é composta, em sua maioria, por indivíduos pequenos $(<1,4 \mathrm{~cm})$, os quais representam até $74 \%$ da população coletada.

PALAVRAS-CHAVE. Invasão de água doce, frequência de tamanhos, mexilhão-dourado, bivalve.

Limnoperna fortunei (Dunker, 1857) (Bivalvia, Mytilidae), commonly known as golden mussel, was first detected in the Americas at the River Plate (Bagliardi Bathing Resort), coast of Argentina, in September 1991 (Langone, 2005). This invasive bivalve, native of Southeast Asia, has expanded rapidly in the River Plate estuary and it reached the major rivers in the Uruguay River basin (LANGONE, 2005). In 1999 it was observed at the northern end of Patos' Lagoon (Mansur et al.,1999). After the colonization, the southern dispersion of $L$. fortunei for estuarial portion occurred.

The species gradually invaded the Southern lagoon (CAPitoli \& Bemvenuti, 2004; Piedras et al., 2007; Bemvenuti \& Colling, 2010), being registered in 2005 in the drainage basin of Mirim Lagoon (LANGONE, 2005; BuRns et al., 2006b), crossing the barrier of the São Gonçalo Channel Sluice Dam, probably due to boats translated from Patos' Lagoon, as it was predicted by Capitoli \& BemVenuti (2004) and Langone (2005).

According to MANsuR et al. (2003), five years after the species invasion in the system of Patos lagoon, the golden mussel population in Lake Guaíba reached 140,000 ind./ $\mathrm{m}^{2}$, and then stabilized at averages 40.000 to 80.000 ind./ $\mathrm{m}^{2}$. Likewise, São Gonçalo Channel, due to its limnological characteristics, can provide a favorable environment for high colonization of $L$. fortunei, which would affect the structure and functioning of this system, as it is observed in other environments (DARRIGRAN et al., 1998; DARRIGRAN, 2002).
Thus, knowledge about the abundance of species may lead to a more accurate prediction of the dispersion levels and a greater understanding of the biology of invasive species (Johnson \& PADILla, 1996). In this sense, the present work describes the space-time variation of the golden mussel in São Gonçalo Channel, three years after recording their presence in this system.

\section{MATERIALS AND METHODS}

The study area comprises the limnic portion of São Gonçalo Channel. This channel is a connection between the Mirim and Patos lagoons located at the southern Brazil, and its water may flow in both directions, depending on the water levels of the lagoons and the wind action. The limnic region of São Gonçalo channel embraces from the Sluice Dam until a place named Sangradouro in the Mirim Lagoon (Kotzian \& Marques, 2004) and it presents depths of 3 to $6 \mathrm{~m}$ in its $61 \mathrm{~km}$ of extension. The dam was built in 1977 about 20 $\mathrm{km}$ from the confluence with Patos'Lagoon, in order to prevent the entry of salt water from the estuarine region of Patos'Lagoon to Mirim Lagoon, in periods of severe drought (Burns et al., 2006a).

Three regions of samples were determined from the Sluice Dam to the confluence with Piratini river (Sluice, S $36^{\circ} 93^{\prime} 15$, W 64 $80^{\circ} 392$; Tigre, S $36^{\circ} 85^{\prime} 36$, W $64^{\circ} 76^{\prime} 783$;

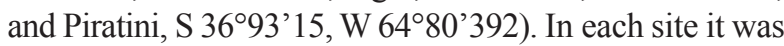


obtained measurements of temperature, $\mathrm{pH}$, and dissolved oxygen using an YSI model mini probe.

Seasonally (February 2008 to January 2009) in each region of collection, it was performed four samples of bottom trawl, at depths between 3 and $6 \mathrm{~m}$, using trawl doors $(15 \mathrm{~kg}$ each) with the following characteristics: $10.5 \mathrm{~m}$ opening ( $6 \mathrm{~kg}$ of lead in the bottom mesh), $0.8 \mathrm{~m}$ high and $7.5 \mathrm{~m}$ in length with $18 \mathrm{~mm}$ mesh in the wings and $5 \mathrm{~mm}$ in the bag, dragged by a wooden boat (12 $\mathrm{m}$ long) equipped with engines of $60 \mathrm{HP}$. Each sample lasted 5 minutes, which equates to about $400 \mathrm{~m}$ trawling (Lopes et al., 2009).

Samples collected were weighed, stored in plastic bags and taken to the laboratory and voucher specimens housed at the Instituto de Oceanografia, Universidade Federal do Rio Grande (FURG). Collections with more than $1 \mathrm{~kg}$ of golden mussel were weighed aboard and three aliquots of known weight were taken $(100 \mathrm{~g})$. All samples were preserved in alcohol $70 \%$.

The estimate of total quantity of mussels caught by trawling was accomplished by the average number of individuals from three aliquots of known weight, and extrapolated to the total weight of the sample through rule of three. From each aliquot, up to 300 specimens were randomly selected, and measured at their maximum length (distance from anterior end, situated just above and ahead of umbones up to the posterior end of the shell) (MANSUR et al., 1987) using a digital caliper with precision of $0.01 \mathrm{~mm}$, and weighed on scales with a precision of $0.01 \mathrm{~g}$.

Individuals over $0.5 \mathrm{~cm}$ in length were considered adults (DARRIGRAN et al., 1999), and individuals below $0.5 \mathrm{~cm}$ were considered recruits, and not included in the analysis. Length measurements were grouped in intervals of $0.2 \mathrm{~cm}$. Later, due to its presumed greater mobility, individuals smaller than $1.4 \mathrm{~cm}$ (class 1.2) were classified as small and individuals larger than 1.4 $\mathrm{cm}$ as large (URYU et al., 1996).

The relative abundance of golden mussel was estimated by CPUE (Catch per Unit Effort), that consists of the ratio between the sum of the total number of estimated individuals divided by the capture effort. The relative abundance of small individuals $(<1.4 \mathrm{~cm})$ and large $(>$ $=1.4 \mathrm{~cm})$ was estimated using the technique of CPUE$\mathrm{TL}$ (catch per unit effort by total length class) (VIEIRA, 2006), which consists of calculating the ratio between the sum of the weighting factor [WF $=\mathrm{N} / \mathrm{n}$, where $\mathrm{N}$ is the number of individuals (small or large) captured in the sample, and $\mathrm{n}$ is the number of small or large individuals measured] divided by the effort [ $\Sigma W F(T L) / e f f o r t]$.

After logarithmic transformation $\left(\log _{10}+1\right)$, differences between the total abundance (CPUE), abundance of small (CPUE-SMA) or large (CPUELAR), by yearly season and location were tested using two-way analysis of variance, and through the Tukey test HSD ( $\alpha=0.05)$, after meeting the assumptions of conditions of normality, homogeneity and variance (ZAR, 1999).

The trawling area calculation was performed through the "Swept Area Method" (FAO, 1997), which consists of estimating the swept area by multiplying the distance of the trawling $(\mathrm{D}=$ estimated at $400 \mathrm{~m})$ by the length of the bottom mesh of the net $(\mathrm{R}=10.5 \mathrm{~m})$, taking into account its fraction that actually remains stretched during the trawling ( $\mathrm{f}=$ estimated at 0.5 ), according to the formula: Swept Area A = D x R x f, which resulted in an estimate of $2,100 \mathrm{~m}^{2}$ per trawling. Densities of L. fortunei were estimated considering the swept area estimated.

\section{RESULTS}

Table I presents the mean values of water temperature, $\mathrm{pH}$ and $\mathrm{DO}$ recorded for the sites. Water temperature showed seasonal fluctuation in the three collection points of São Gonçalo Channel, with a minimum of $12.4^{\circ} \mathrm{C}$ recorded in September 2008 and a maximum of $24.3^{\circ} \mathrm{C}$ in January 2009. The annual average was $18.4^{\circ} \mathrm{C}$. The minimum values of $\mathrm{pH}(6.0)$ and DO $(1.8 \mathrm{mg} / \mathrm{L})$ were observed during November and the maximum values ( 8.1 and 10.5 respectively) achieved in June 2008.

Our samples revealed the presence of $L$. fortunei, in water depths ranging between 3 and $6 \mathrm{~m}$, (bottom trawling) in most samples (FO\% $>58 \%$ of total samples). A total of 456,735 individuals were collected. The estimated mean density for the deep region of São Gonçalo Channel ranged from 1.2 to 10.3 ind.$/ \mathrm{m}^{2}$, being recorded a maximum density of 84.9 ind. $/ \mathrm{m}^{2}$ in the fall of 2008 (Tab. II).

The estimates of mean relative abundance (CPUE) ranged from 2,425.3 ind./drag in the spring to 21,715.1 ind./drag in the fall, with an average of 9,515.3 ind./drag throughout the year. ANOVA results revealed that the interaction between site and sampling period was not significant ( $p>0.95358)$, and there was no significant difference between the averages of CPUE of the golden mussel, both between yearly seasons ( $>0.71115)$ and between collection sites $(p>0.76696)$, whereas the apparent difference between the averages is suppressed by data variation.

ANOVA results show that both CPUE-SMA and

Tab. I. Mean, minimum and maximum values for water temperature, $\mathrm{pH}$ and DO (concentration of dissolved oxygen) obtained during collections in São Gonçalo Channel, state of Rio Grande do Sul, Brazil throughout the year 2008.

\begin{tabular}{lcccc}
\hline Variables & Mean & Standard Deviation & Standard Error & Minimum \\
\hline Water $\left({ }^{\circ} \mathrm{C}\right)$ & 18.46 & 4.78 & 4.58 & 12.40 \\
$\mathrm{pH}$ & 7.01 & 0.99 & 0.95 & 6.00 \\
$\mathrm{DO}$ & 6.36 & 4.04 & 3.87 & 8.11 \\
\hline
\end{tabular}


Tab. II. Temporal variation in the relative abundance of Limnoperna fortunei (Dunker, 1857) collected in São Gonçalo Channel, state of Rio Grande do Sul, Brazil during the year 2008.

\begin{tabular}{lccccccc}
\hline & $\mathrm{N}$ & Mean/trawling & $\begin{array}{c}\text { Standard } \\
\text { Deviation }\end{array}$ & Minimum & Maximum & Dens/mean & FO $\%$ \\
Fall & 260,581 & $21,715.08$ & $54,006.47$ & 0 & 178376 & 10.34 & 66.67 \\
Winter & 31,421 & $2,618.42$ & $6,845.86$ & 0 & 24135 & 1.25 & 75.00 \\
Spring & 29,104 & $2,425.33$ & $3,242.99$ & 0 & 9206 & 1.15 & 58.33 \\
Summer & 135,629 & $11,302.42$ & $12,240.06$ & 0 & 28109 & 5.38 & 75.00 \\
Total & 456,735 & $9,515.31$ & $28,194.34$ & 0 & 178376 & 4.53 & 68.75 \\
\hline
\end{tabular}

CPUE-LAR, the interactions between site and yearly period of collections were not significant $(\mathrm{p}>0.97587$ and $\mathrm{p}>0.86621$ ), and there is no significant difference between averages, both among yearly seasons $(\mathrm{p}=$ 0.60335 and $\mathrm{p}=0.58218)$, and among collection sites $(\mathrm{p}=0.78896$ and $\mathrm{p}=0.75448)$, whereas the apparent difference between averages is suppressed by data variation.

The total shell length of specimens measured $(n=$
7,776 ) ranged between $0.4 \mathrm{~cm}$ and $3.2 \mathrm{~cm}$. After removal of individuals smaller than $0.5 \mathrm{~cm}$ (see Materials and Methods) the size distribution was unimodal, with mode in the class of $1.2 \mathrm{~cm}(1.2$ to $1.39 \mathrm{~cm})$ throughout the year. Individuals classified as small $(<1.4 \mathrm{~cm})$ were more abundant than large individuals $(>=1.4 \mathrm{~cm})$ in the three collection sites, representing $74 \%$ of the total collected in the region of Sluice and Tigre, and 57\% in Piratini (Fig. 1).
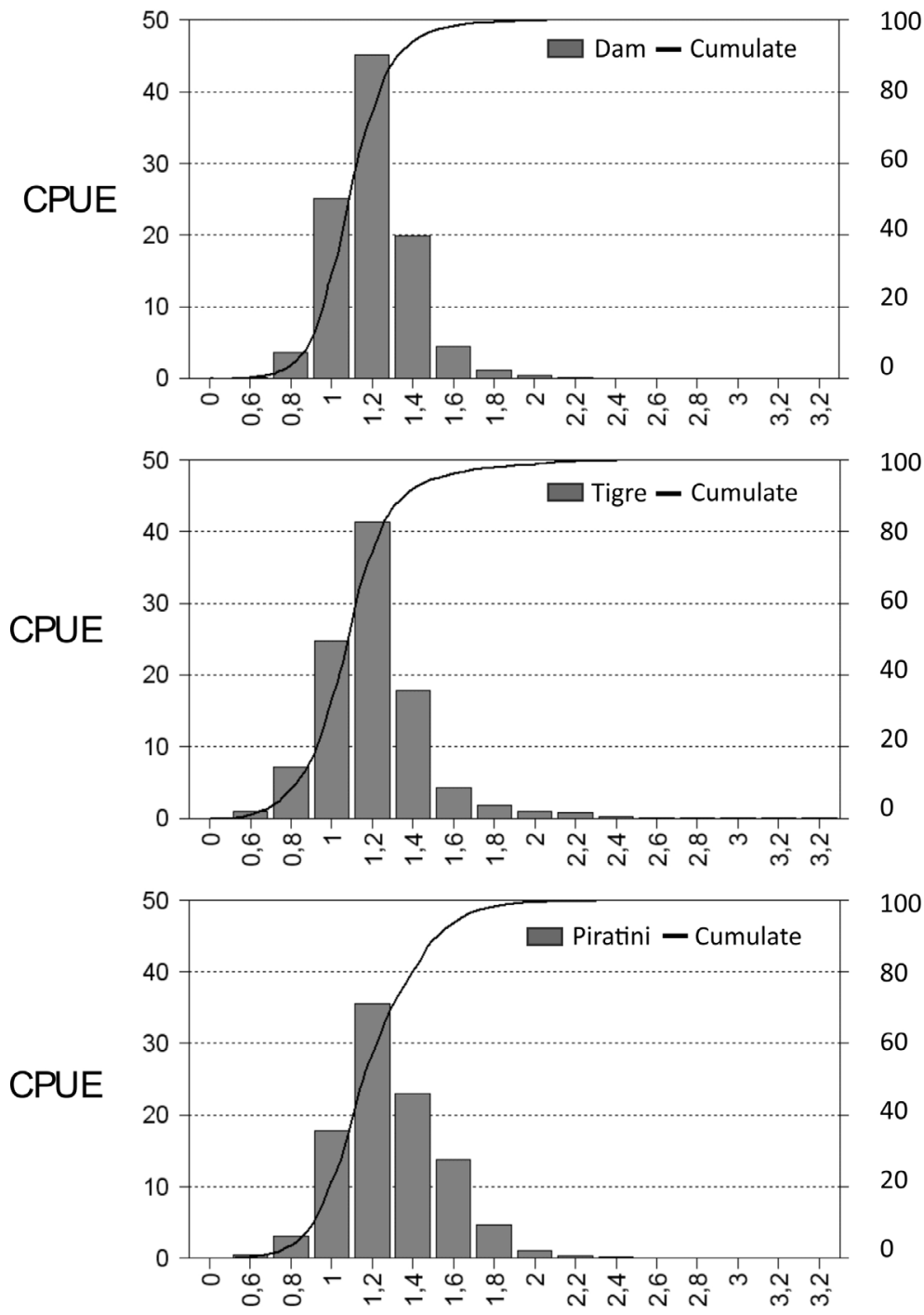

Classes of shell length of $L$. fortunei $(\mathrm{cm})$

Fig. 1. Frequency in percentage of CPUE (CPUE "estimative of mean relative abundance") of individuals of Limnoperna fortunei (Dunker, 1857) collected (Y1 axis) and cumulative curve of CPUE (\%) (Y2 axis), distributed in the 14 classes of total length captured (X axis) in the three collection points of São Gonçalo Channel, state of Rio Grande do Sul, Brazil. 


\section{DISCUSSION}

The maximum density point observed (84.9 ind./ $\mathrm{m}^{2}$ ) and the high incidence of samples without golden mussel reveal a distribution in aggregate and not uniformly over the bottom of São Gonçalo Channel (Tab. II). In fact, the evaluation of golden mussel mean density in large areas is complicated, because the groups formed by L. fortunei have an extremely unequal distribution, which is associated not only with the availability of substrate as well as his gregarious behavior (BOLTOvSKOY et al., 2006). Our method of sampling (5-minute bottom trawling) covers a very extensive area $\left(2,100 \mathrm{~m}^{2}\right)$ with results of about $400 \mathrm{~m}$ trawling with a net that opens about $5 \mathrm{~m}$. On the other hand, collection protocols used in several studies (scraping of natural substrate or provision of artificial substrate) has recorded high densities of golden mussel, with colonies reaching about 150,000 ind. $/ \mathrm{m}^{2}$ in Argentina (DARRIGRAN \& EzCURRA DE Drago, 2000) and 140,000 ind. $/ \mathrm{m}^{2}$ in Lake Guaíba (MANsur et al., 2003).

Low densities recorded in this study under the bottom of São Gonçalo Channel can be attributed to the large areas swept $(400 \mathrm{~m})$ and the gregarious behavior of the mussel. The same was observed for another invasive mussel Dreissena polymorpha (zebra mussel) in the Great Lakes region in North America, where large clusters were recorded and distributed unequally under the soft sediments at greater depths (COAKLEY et al., 1997).

Studies with zebra mussels in North America described clusters of individuals united only by the byssus thread of each other and the grains of sand of soft sediments, and which have densities similar to populations that colonize hard substrates (BERKMAN et al., 2000). Among the specimens of $L$. fortunei captured in this study, the highest concentrations of individuals were of loose organisms or organisms just adhered together, forming loose curls under the soft bottom of the channel, suggesting the same behavior reported for the zebra mussel. However, some specimens were fixed to the bottom debris such as stones, bricks, logs, other bivalves, or even crustaceans as reported by LOPES et al. (2009).

The relative abundance of $L$. fortunei recorded throughout the year, with average of 9,515.3 ind./ drag, demonstrates the capacity for colonization and establishment of the species under the muddy bottom of São Gonçalo Channel. Environmental parameters studied were within the limits suggested for the species (DARRIGRAN, 2002), and their constancy of occurrence in samples $(\mathrm{FO}=58 \%)$ reveals that the species has been completely established in the system, and in high availability, being a possible source of food especially for fishes.

The frequency of sizes distribution of $L$. fortunei captured under the bottom of São Gonçalo Channel showed a wide variation $(0.4$ to $3.2 \mathrm{~cm})$. The method of collection with bottom trawl (net mesh $0.5 \mathrm{~cm}$ ) enabled the capture of individuals mostly larger than $0.5 \mathrm{~cm}$, showing that the structure of the adult population under the bottom of São Gonçalo Channel is composed mostly of small individuals $(<1.4 \mathrm{~cm})$, which represent $70 \%$ of the population collected.

The predominance of small individuals, smaller than $1.4 \mathrm{~cm}$, under the muddy bottom of São Gonçalo Channel reflects the behavior of greater mobility of these individuals, as suggested by URYU et al. (1996) and Bergonci et al. (2009). As the individuals grow, they lose mobility and seek protected places, forming clusters. Over approximately $3 \mathrm{~cm}$ they can no longer move on the substrate, remaining aggregated until the end of their life cycle (URYu et al., 1996).

Results of research not yet published, the authors observed still that individuals smaller than $1.4 \mathrm{~cm}$ dominate in the stomach contents of pintado (Pimelodus pintado) collected in São Gonçalo Channel, as well as other benthophagous species. These data support the hypothesis proposed by authors for greater mobility of small individuals (smaller than $1.4 \mathrm{~cm}$ ), and their consequent greater availability and vulnerability to predation by fishes.

Future investigations associating bottom trawling and technological equipment such as Side Scan Sonar, can contribute in a comprehensive way in filling the gaps in the knowledge about the gregarious behavior of $L$. fortunei, contributing for a better understanding of ecological interactions and changes in habitat that the species could make.

Acknowledgements. The authors thank CNPq (Conselho Nacional de Desenvolvimento Científico e Tecnológico) from their financial support and personal grants.

\section{REFERENCES}

Bemvenuti, C. E. \& Colling, L. A. 2010. As comunidades de macroinvertebrados bentônicos. In: SEeliger, U. \& Odebrecht, C. eds. 2010. O estuário da Lagoa dos Patos: um século de transformações. Rio Grande, FURG. 180p.

Bergonci, P. E. A.; Mansur, M. C. D.; Pereira, D. \& Santos, C. P. 2009. Population sampling of the golden mussel, Limnoperna fortunei (Dunker, 1857), based os artificial ceramic substrate. Biotemas 22(3):85-94

Berkman, P. A.; Garton, D. W.; Haltuch, M. A.; Kennedy, G. W. \& FeBo, L. R. 2000. Habitat shift in invading species: zebra and quagga mussel population characteristics on shallow soft substrates. Biological Invasions 2:1-6.

Boltovskoy, D.; Correa, N.; Cataldo, D. \& Sylvester, F. 2006. Dispersion and ecological impact of the invasive freshwater bivalve Limnoperna fortunei in the Río de la Plata watershed and beyond. Biological Invasions 8:947-963.

Burns, M. D.; Garcia, A. M.; Vieira, J. P.; Bemvenuti, M. A.; Motta Marques, D. M. L. \& Condini, V. 2006a. Evidence of fragmentation affecting fish movement between Patos and Mirim coastal lagoons in southern Brazil. Neotropical Ichthyology 4(1):69-72

Burns, M. D.; Geraldi, R. M.; Garcia, A. M.; Bemvenuti, C. E.; Capitoli, R. R. \& Vieira, J. P. 2006b. Primeiro registro de ocorrência do mexilhão dourado Limnoperna fortunei na Bacia de drenagem da Lagoa Mirim, RS, Brasil. Notas e Resenhas. Biociências 14(1):83-84. 
Capítoli, R. R. \& Bemvenuti, C. E. 2004. Distribuição do mexilhão dourado Limnoperna fortunei (Dunker, 1857) na área estuarina da lagoa dos Patos e Canal São Gonçalo. In: Anais do VI Simpósio de Ecossistemas Brasileiros. Publicações ACIESP 110(1):98100.

Coakley, J. P.; Brown, G. R.; Ioannou, S. E. \& Charlton, M. N. 1997. Colonization patterns and densities of Zebra Mussel Dreissena in Muddy offshore sediments of Western Lake Erie, Canada. Water, Air and Soil Pollution 99:623-632.

Darrigran, G. 2002. Potencial impact of filter-feeding invaders on temperate inland freshwater environments. Biological Invasions 4:145-156.

Darrigran, G.; Martin, S. M.; Gullo, B. \& Armendariz, L. 1998. Macroinvertebrates associated with Limnoperna fortunei (Dunker, 1857) (Bivalvia, Mytilidae) in Rio de la Plata, Argentina. Hydrobiologia 367:223-230.

Darrigran, G.; Penchaszadeh, P. \& Damborenea, M. C. 1999. The reproductive cycle of Limnoperna fortunei (Dunker,1857) (Mytilidae) from a neotropical temperate locality. Journal of Shellfish Research 8(2):361-365.

Darrigran, G. A. \& Ezcurra DE Drago, I. 2000. Invasión of Limnoperna fortunei (Dunker, 1857) (Bivalvia: Mytilidae) in America. Nautilus 2:69-74.

FAO. 1997. Introdução à avaliação de mananciais de peixes tropicais. Parte 1: Manual. Documento Técnico sobre as Pescas (No. 306/1, Rev. 2). Roma, FAO. 404p.

Johnson, L. E. \& Padilla, D. K. 1996. Geographic spread of exotic species: ecological lessons and opportunities from the invasion of zebra mussel Dreissena polymorpha. Biological Conservation 78:23-33.

Kotzian, H. B. \& Marques, D. M. 2004. Lagoa Mirim e a convenção Ramsar: um modelo para ação transfronteiriça na conservação de recursos hídricos. Revista de Gestão de Água da América Latina 1(2):101-111.
LANGOne, J. A. 2005. Notas sobre el mejillón dorado Limnoperna fortunei (Dunker, 1857) (Bivalvia, Mytilidae) en Uruguay. Publicación extra del Museo Nacional de Historia Natural y Antropologia Montevideo 1:1-17.

Lopes, M. N.; Vieira, J. P. \& Burns, M. D. M. 2009. Biofouling of the golden mussel Limnoperna fortunei (Dunker, 1857) over the Anomura crab Aegla platensis Schmitt, 1942. Pan-American Journal of Aquatic Sciences 4(2):222-225.

Mansur, M. C. D.; Richinitti, L. M. Z. \& Santos, C. P. 1999. Limnoperna fortunei (Dunker, 1857) molusco bivalve invasor na bacia do Guaíba, Rio Grande do Sul, Brasil. Biociências 7(2):147149.

Mansur, M. C. D.; Schulz, C. \& Garces, L. M. M. P. 1987. Moluscos bivalves de água doce: identificação dos gêneros do sul e leste do Brasil. Acta Biologica Leopoldensia 9(2):181-202.

Mansur, M. C. D.; Santos, C. P.; Darrigran, G.; Heydrich, I.; Callil, C. T. \& Cardoso, F. R. 2003. Primeiros dados quali-quantitativos do mexilhão dourado, Limnoperna fortunei (Dunker, 1857) no Delta do Jacuí, no lago Guaíba e na Laguna dos Patos, Rio Grande do Sul, Brasil e alguns aspectos de sua invasão no novo ambiente. Revista Brasileira de Zoologia 20(1):75-84.

Piedras, S. R.; BAger, A. \& CorrêA, F. 2007. Ocorrência de Limnoperna fortunei (Dunker, 1857) (Mytilidae) durante um período de salinização do baixo Arroio Pelotas, Pelotas, Rio Grande do Sul. Boletim do Instituto de Pesca 33(1):121-125.

Uryu, Y.; Iwasaky, K. \& Hinque, M. 1996. Laboratory experiments on behaviour and movement of a freshwater mussel, Limnoperna fortunei (Dunker, 1857). Journal of Molluscan Studies 62:327341.

VIEIRA, J. P. 2006. Ecological analogies between estuarine bottom trawl fish assemblages from Patos Lagoon (32S), Brazil, and York River (37N), USA. Revista Brasileira de Zoologia 23(1):234-247.

ZAR, J. H. 1999. Biostatistical Analysis. New Jersey, Prentice Hall. $662 \mathrm{p}$.

Recebido em 30 de dezembro de 2011. Aceito 15 de outubro de 2012. ISSN 0073-4721

Artigo disponível em: www.scielo.br/isz 